\begin{tabular}{|c|c|c|}
\hline & Int.J.Curr.Microbiol.App.Sci (2021) 10(08): 545-549 & \\
\hline & $\begin{array}{l}\text { International Journal of Current Micro6iology and Applied Sciences } \\
\text { ISSN: 2319-7706 Volume } \mathbf{1 0} \text { Number } \mathbf{0 8}(\mathbf{2 0 2 1 )} \\
\text { Journal homepage: http://www.ijcmas.com }\end{array}$ & $\begin{array}{l}50 \\
502\end{array}$ \\
\hline $\begin{array}{l}\text { EXCELLENT } \\
\text { PUBLISHERS }\end{array}$ & & whwe.jicmascom \\
\hline
\end{tabular}

\title{
Effect of Time and Environment on Wedge Grafting of Guava (Psidium guajava L.) cv. Sardar
}

\author{
Harish Chandra Yadav ${ }^{1 *}$, Aman Srivastav ${ }^{1}$, Astha Pal ${ }^{1}$, Virendra K. Patel ${ }^{1}$, \\ Hari Baksh ${ }^{1}$, Rajaneesh Singh ${ }^{1}$, Bijendra K. Singh ${ }^{2}$ and Raj Pandey ${ }^{1}$ \\ ${ }^{1}$ Department of Horticulture, Tilak Dhari Post Graduate College, Jaunpur-222 002, India \\ ${ }^{2}$ Department of Fruit Science, CoH, BUA\&T, Banda, India \\ *Corresponding author
}

\section{A B S T R A C T}

Keywords

Psidium guajava,

mango, banana and citrus

Article Info

Accepted:

20 July 2021

Available Online:

10 August 2021
An experiment was conducted at the farm of Krishi Bhawan, Jaunpur during 2018-19 to study the "Effect of time and environment on wedge grafting of guava (Psidium guajava L.) cv. Lucknow - 49 (Sardar)". The result indicated that minimum number of days (25) required for sprouting of bud was significant in the month of July. Highest bud sprouting percentage $(36.77 \%)$, maximum number of leaves (47.06), maximum width of leaves $(6.22 \mathrm{~cm})$, maximum scion shoot diameter $(0.87 \mathrm{~cm})$, maximum length of rootstock $(16.97 \mathrm{~cm})$ and highest success percentage $(34.82 \%)$ also recorded in July. Whereas the maximum plant height $(64.95 \mathrm{~cm})$ and maximum length of scion shoots $(39.05 \mathrm{~cm})$ was performed in March. Significantly maximum rootstock diameter $(1.47 \mathrm{~cm})$ and maximum leaf length $(13.29 \mathrm{~cm})$ was recorded in October. Maximum number of primary branches (6.37) performed in November and highest mortality percentage $(88.96 \%)$ was noticed in April.

\section{Introduction}

Guava (Psidium guajava L.) popularly known as 'apple of tropics' is native to the tropical America region stretching from Mexico to Peru. It is widely distributed throughout the tropical and subtropical regions of the world. At present, major guava producing countries are south Asian countries Hawaiian Islands,
Cuba and India (Kumar et al., 2011). Guava belongs to the family Myrtaceae and the recognition of being the most widely cultivated species of this family. Guava was introduced to India during $17^{\text {th }}$ century. It is a popular fruit crop due to its prolific bearing and good remuneration. Guava is the fourth most important fruit crop in area and production after mango, banana and citrus. It 
occupies $4.07 \%$ of total fruit crop area in the country with $4.16 \%$ production share. The area under guava during 2017-18 was about $265 \mathrm{~m}$-ha with production $4054 \mathrm{mt}$ and productivity $15.3 \mathrm{~T} / \mathrm{ha}$. In India it is grown in almost all states; however, Uttar Pradesh, Madhya Pradesh, Bihar, Chhatishgharh, West Bengal, Odisha, Gujarat, Haryana, Maharashtra, Punjab, Karnataka and Andhra Pradesh are the leading guava growing states. The state of Uttar Pradesh has highest $49.53 \mathrm{~m}$ ha area with highest 928.44 M.T production and leading state in productivity is Andhra Pradesh with 24.12 T/ha (Ministry of Agriculture and Farmer's Welfare, Govt. of India).

Guava can be propagated by vegetative methods as it gave advantages over seed propagation as it reduces juvenility and maintain uniformity in the planting material. Success rate of propagation techniques varies with climatic factors and season of grafting. Vegetative methods of propagation have employed in guava in different part of the country. However, season of propagation techniques varies from region to region due to the variation in agro-climatic condition.

Wedge grafting has a tremendous potential for multiplying guava plants rapidly throughout the year either in greenhouse as well as in open conditions. But studies related to the suitable time of grafting are not sufficient to standardize this technique over a large geographical area. Therefore, the present study was planned to standardize the time of wedge grafting for achieving higher success percent.

\section{Materials and Methods}

The present investigation entitled "Effect of time and environment on wedge grafting of guava (Psidium guajava L.) cv. Lucknow - 49 (Sardar)" was carried out during the 2018-19.
The experiment was conducted at the farm of Krishi Bhawan, Jaunpur, Uttar pradesh. Geographically Jaunpur is situated between $25^{\circ} 44^{\prime} 0$ " latitude in the north and $82^{\circ} 41^{\prime} 0$ " longitude in the east at an elevation of 83.230 meter above mean sea level. The total geographical area of Jaunpur division comes under Eastern zone of Uttar Pradesh. The climatic condition of Jaunpur is sub-tropical with three distinct seasons i.e., winter, summer and rainy. During the winter season (December to January) temperature fall $5^{\circ} \mathrm{C}$ or even low, while in summer season (May to June) it reaches as high as $45^{\circ} \mathrm{C}$. Occasional spell of frost and precipitation may occur during winter. Most of the rainfall is received in the middle of July to end of September after which the intensity of rainfall decreases. The mean annual rainfall is about 850 to $1100 \mathrm{~mm}$.

The treatments were viz. $\mathrm{T}_{1}-\left(15^{\text {th }}\right.$ march $), \mathrm{T}_{2}$ (14 ${ }^{\text {th }}$ April $), \mathrm{T}_{3}-\left(14^{\text {th }}\right.$ May $), \mathrm{T}_{4}-\left(13^{\text {th }}\right.$ June $)$, $\mathrm{T}_{5}-\left(13^{\text {th }}\right.$ July $), \mathrm{T}_{6}-\left(12^{\text {th }}\right.$ August $), \mathrm{T}_{7}-\left(11^{\text {th }}\right.$ September $) \mathrm{T}_{8}-\left(11^{\text {th }}\right.$ October $)$ and $\mathrm{T}_{9}-\left(10^{\text {th }}\right.$ November) evaluated in factorial randomized block design with three replications.

One year old healthy and uniform seedlings of guava having a diameter of 0.75 to $1.0 \mathrm{~cm}$ and height of 50 to $60 \mathrm{~cm}$ were used as rootstock for the entire study. The seedlings were maintained healthy by using appropriate cultural practices during the course of investigation. Proper selection and preparation of scion sticks are very important for obtaining higher success in wedge grafting. Therefore, 3 to 4 months old $16 \mathrm{~cm}$ long scion shoots of pencil thickness $(0.75$ to $1.0 \mathrm{~cm})$ having 3 to 4 healthy buds were used for wedge grafting. These selected shoots were then defoliated on the mother plant leaving the petiole attached, about 5 to 7 days prior to its detachment from mother trees. At the same time, the apical growing portion of selected shoot was also beheaded. This helped in forcing the dormant buds to swell. After 
selecting the scion, the root stock was headed back at the height of $15 \mathrm{~cm}$. The beheaded root stock was then split open $4 \mathrm{~cm}$ deep through the centre from the cut end of the stock with the help of grafting knife. A wedge shaped slanting cut from both the sides $(4 \mathrm{~cm}$ long) was made at the proximal end of the scion shoot. The scion stick was then inserted into the split portion of the stock and pressed properly so that the cambium tissues of root stock and scion stick overlap each other. The stock and scion combination was then tied with the help of $2 \mathrm{~cm}$ wide and $25 \mathrm{~cm}$ long polyethylene (strip150 gauges). The polyethylene strip was removed as soon as the buds started to sprout.

For testing the hypothesis the following ANOVA table was used. The significance and non-significance treatment effect was judged with the help of ' $F$ ' variance ratio test. Calculated ' $F$ ' value was compared with the table value of ' $F$ ' at $5 \%$ levels of significance. If calculated value exceeds the table value, the effect was considered to be significant. The significant difference between the means was tested critical difference at 5\% level of significance.

\section{Results and Discussion}

The data (Table $1 \&$ Table 2 ) revealed that there was a steady rise in days taken to sprouting, sprouting percentage (\%), diameter of scion shoot $(\mathrm{cm})$, length of rootstock $(\mathrm{cm})$, number of leaves per budded/grafted plants, leaf width $(\mathrm{cm})$ and success percentage $(\%)$ (25.13 days, $36.77 \%, 0.87 \mathrm{~cm}, 16.97 \mathrm{~cm}$, $47.06,6.22 \mathrm{~cm}$ and $34.82 \%$ ) respectively were encountered in July. The findings are in conformity with the findings of Rao et al., (1984) who had observed early bud sprouting when grafting was done during July. Likewise, the studies of other researchers working on different crops supported these findings. For example, Kumar and Mitra (1994) had observed early bud sprouting in mango when grafting was done during July and August.

Studies in guava observed early bud sprouting in plants budded in the month of May and June (Rao et al., 1977).

In this study, highest bud and graft success were recorded during the month of July. Also the grafts made during July exhibited more sprouting closely followed by the grafts prepared in August and September. Rao et al., (1984) also obtained maximum graft success per cent in the month of July. The higher success in July and August in the present study might be because of congenial environmental conditions prevailing during the period following grafting and rapid sap flow in stock and scion which might have favoured the healing process and as a result established the continuity of cambial and vascular tissues for sprouting and ultimately higher plant survival (Chandel et al., 1998; Pathak and Srivastava, 1973).

Maximum plant height $(\mathrm{cm})$ and length of scion shoot (cm) (64.95 and 39.05) respectively performed in March. Singh and Sengupta (1996) also recorded maximum sprout length in the plants grafted during March. The higher plant and scion length recorded in plants grafted in March and April in the present study may be because of the fact that grafted plant faced long periods of rainy season. Maximum diameter of rootstock (1.53 $\mathrm{cm})$ and maximum leaf length $(13.29 \mathrm{~cm})$ were found in the month of October. Whereas maximum numbers of primary branches per budded/grafted plants (6.37) were performed in November and maximum mortality percentage $(88.96 \%)$ was noticed in April. Similar observations were recorded by Upadhayay and Prasad, (1988) while working on mango. 
Table 1

\begin{tabular}{|c|c|c|c|c|c|c|c|c|}
\hline Months & Treatments & $\begin{array}{c}\text { Day } \\
\text { taken to } \\
\text { sprouting }\end{array}$ & $\begin{array}{c}\text { Sprouting } \\
\text { percentage }\end{array}$ & $\begin{array}{c}\text { Diameter } \\
\text { of scion } \\
\text { shoot } \\
\text { (cm) }\end{array}$ & $\begin{array}{c}\text { Length } \\
\text { of } \\
\text { rootstock } \\
\text { (cm) }\end{array}$ & $\begin{array}{c}\text { Number } \\
\text { of } \\
\text { leaves }\end{array}$ & $\begin{array}{c}\text { Leaf } \\
\text { width(cm) }\end{array}$ & $\begin{array}{c}\text { Success } \\
\text { percentage } \\
(\mathbf{\%})\end{array}$ \\
\hline 15 march & $\mathrm{T}_{1}$ & 26.06 & 26.74 & 0.64 & 16.06 & 45.63 & 5.20 & 21.48 \\
\hline 14 April & $\mathrm{T}_{2}$ & 29.04 & 13.61 & 0.16 & 16.00 & 40.69 & 6.04 & 11.9 \\
\hline 14 May & $\mathrm{T}_{3}$ & 0.00 & 0.00 & 0.00 & 0.00 & 0.00 & 0.00 & 0.00 \\
\hline 13June & $\mathrm{T}_{4}$ & 0.00 & 0.00 & 0.00 & 0.00 & 0.00 & 0.00 & 0.00 \\
\hline 13 July & $\mathrm{T}_{5}$ & 25.13 & 36.77 & 0.87 & 16.97 & 47.06 & 6.22 & 34.82 \\
\hline 12 August & $\mathrm{T}_{6}$ & 27.52 & 33.51 & 0.84 & 15.81 & 35.85 & 5.85 & 30.82 \\
\hline 11september & $\mathrm{T}_{7}$ & 29.24 & 30.69 & 0.69 & 16.12 & 30.03 & 5.84 & 27.09 \\
\hline 11October & $\mathrm{T}_{8}$ & 32.34 & 26.84 & 0.77 & 16.10 & 32.83 & 5.51 & 21.74 \\
\hline 10november & $\mathrm{T}_{9}$ & 34.94 & 20.92 & 0.73 & 16.19 & 35.03 & 5.43 & 16.89 \\
\hline Mean & & $\mathbf{2 2 . 6 5}$ & $\mathbf{2 1 . 0 1}$ & $\mathbf{0 . 5 7}$ & $\mathbf{1 2 . 5 8}$ & $\mathbf{2 9 . 7 4}$ & $\mathbf{4 . 4 5}$ & $\mathbf{1 8 . 3 4}$ \\
\hline
\end{tabular}

Table 2

\begin{tabular}{|c|c|c|c|c|c|c|c|}
\hline Month & treatments & $\begin{array}{c}\text { Plant } \\
\text { height } \\
\text { (cm) }\end{array}$ & $\begin{array}{c}\text { Length } \\
\text { of scion } \\
\text { shoot } \\
\text { (cm) }\end{array}$ & $\begin{array}{c}\text { Diameter } \\
\text { of scion } \\
\text { shoot } \\
\text { (cm) }\end{array}$ & $\begin{array}{c}\text { Leaf } \\
\text { length } \\
\text { (cm) }\end{array}$ & $\begin{array}{c}\text { Number } \\
\text { of } \\
\text { primary } \\
\text { branches }\end{array}$ & $\begin{array}{c}\text { Mortality } \\
\text { percentage } \\
(\mathbf{\%})\end{array}$ \\
\hline 15 march & $\mathrm{T}_{1}$ & 64.95 & 39.05 & 1.13 & 11.91 & 5.54 & 77.89 \\
\hline 14 April & $\mathrm{T}_{2}$ & 58.92 & 33.84 & 1.18 & 12.88 & 4.90 & 88.96 \\
\hline 14 May & $\mathrm{T}_{3}$ & 0.00 & 0.00 & 0.00 & 0.00 & 0.00 & 0.00 \\
\hline 13June & $\mathrm{T}_{4}$ & 0.00 & 0.00 & 0.00 & 0.00 & 0.00 & 0.00 \\
\hline 13 July & $\mathrm{T}_{5}$ & 59.00 & 34.28 & 1.14 & 12.99 & 6.22 & 65.17 \\
\hline 12 August & $\mathrm{T}_{6}$ & 54.48 & 30.49 & 1.29 & 12.47 & 5.97 & 69.17 \\
\hline 11september & $\mathrm{T}_{7}$ & 52.73 & 29.36 & 1.19 & 12.75 & 5.25 & 72.90 \\
\hline 11October & $\mathrm{T}_{8}$ & 54.89 & 31.56 & 1.53 & 13.29 & 5.45 & 77.99 \\
\hline 10november & $\mathrm{T}_{9}$ & 44.90 & 21.07 & 1.25 & 12.03 & 6.37 & 83.10 \\
\hline Mean & & $\mathbf{4 3 . 3 2}$ & $\mathbf{2 4 . 4 5}$ & $\mathbf{0 . 9 7}$ & $\mathbf{9 . 8 1}$ & $\mathbf{4 . 4 1}$ & $\mathbf{5 9 . 3 7}$ \\
\hline
\end{tabular}

\section{References}

Chandel, J. S., Negi, K. S. and Jindal, K. K. (1998). Studies on vegetative in kiwi (Actinidia deliciousa chev.). Indian J. Hort., 55: 52-54.

Kumar, B., Mistry, N. C., Singh, B. and Gandhi, C. P. (2011). Indian Horticulture Database, National Horticulture Board (NHB), Gurgaon. Department of Agriculture and \&
Cooperation, Govt. of India. Pp. 76-83.

Kumar, S. V. and Mitra, S. K. (1994). Standardization of time and propagation techniques in mango $\mathrm{cv}$. Himsagar. The Hort. J., 7(1): 71-73.

Pathak, R. K. and Srivastava, R. P. (1973). Studies on vegetative propagation of apple by grafting. Prog. Hort., 4: 5764.

Rao, Y. R. and Kaul, G. L. (1977). Effect of kinetin on the success of veneer of 
guava (Psidium guajava L.) in different seasons under tarai conditions of U.P. Indian J. of Horti., 34(2): 137141.

Rao, Y. R., Kaul, G. L. and Suryanarayana, V. (1984). Studies on vegetative propagation of guava (Psidium guajava). Andhra Agric. J., 31(4): 277281.

Singh, G. and Singh, G. P. (2007). Wedge grafting in Guava- A Novel Vegetative Technique. CISH, Lucknow pp.1-12.

Singh, G., Gupta, S. L., Mishra, R. and Singh, A. (2007). Technique for rapid multiplication of guava (Psidium guajava.). Acta Horticulturae, 735: 177-183.

Singh, G., Gupta, S., Mishra, R. and Singh, G. P. (2005). Wedge grafting in guava novel vegetative propagation technique, Pub. CISH, Lucknow. Pp.12.
Singh, G., Gupta, S., Mishra, R., Singh, G. P. and Singh, A. (2005). Technique for rapid multiplication of guava (Psidium guajava L.). Abstracts first International guava symposium, CISH, Lucknow.

Singh, S. and Sengupta, B. N. (1996). Effect of time on soft wood grafting in mango cv. Amrapali. Horticulture Journal, 9(1): 13-16.

Singh, S. and Singh, A. K. (2007). Standardization of method and time of vegetative propagation in tamarind under semi- arid environment of western India. Indian J. Hort., 64(1): 45-49.

Upadhayaya, U. B. and Prasad, R. S. (1988). Effect of time of veneer grafting on sprouting and growth in mango cv. Dashehari. Ind. J. Hort., 45 (1-2): 6162.

\section{How to cite this article:}

Harish Chandra Yadav, Aman Srivastav, Astha Pal, Virendra K. Patel, Hari Baksh, Rajaneesh Singh, Bijendra K. Singh and Raj Pandey. 2021. Effect of Time and Environment on Wedge Grafting of Guava (Psidium guajava L.) cv. Sardar. Int.J.Curr.Microbiol.App.Sci. 10(08): 545549. doi: https://doi.org/10.20546/ijcmas.2021.1008.064 